\title{
Diameter Measurements and Variations of the Hepatic Arterial System in Multidetector Computed Tomography Images
}

\author{
Mediciones de Diámetro y Variaciones del Sistema Arterial Hepático \\ en Imágenes de Tomografía Computarizada Multidetector
}

Abdulkadir Bilir ${ }^{1}$; Zeliha Fazliogullari²; Mustafa Koplay³ ${ }^{3}$ Nadire Unver Dogan² \& Ahmet Kagan Karabulut ${ }^{2}$

BILIR, A.; FAZLIOGULLARI, Z.; KOPLAY, M.; UNVER DOGAN, N. \& KARABULUT, A. K. Diameter measurements and variations of the hepatic arterial system in multidetector computed tomography images Int. J. Morphol., 39(3):869-875, 2021.

SUMMARY: Liver plays an important role in many events such as bile production, blood filtration and metabolic functions. The liver is supplied by the hepatic arterial system. The hepatic arterial system anatomy has a variable structure and the rate of variation is high. In our study, we aimed to determine the diameters and variation of the arteries supplying the liver with multidetector computed tomography images. In this study, hepatic arterial system variations of 500 cases whose abdominal region was imaged with multidetector computed tomography were evaluated and the diameters of the related arteries were measured. The mean diameters of classical and variational anatomy were determined in this study. According to mean measurements of classical and variational anatomy were abdominal aorta $21.95 \mathrm{~mm}$, celiac artery $7.2 \mathrm{~mm}$, common hepatic artery $4.3 \mathrm{~mm}$, proper hepatic artery $2.93 \mathrm{~mm}$, right hepatic artery $2.92 \mathrm{~mm}$, left hepatic artery $2.51 \mathrm{~mm}$ and abdominal aorta $21.85 \mathrm{~mm}$, celiac artery $6.99 \mathrm{~mm}$, common hepatic artery $5.07 \mathrm{~mm}$, proper hepatic artery $3.83 \mathrm{~mm}$, right hepatic artery $2.87 \mathrm{~mm}$ ve left hepatic artery $2.09 \mathrm{~mm}$ respectively. When evaluated in terms of variations, $85.6 \%$ of the cases had branching according to Type I, $14.4 \%$ of the cases had different branching patterns. Type III (87.5\%) was the most observed variation among them. As a result of the study, it was determined that the arterial diameters vary according to the state of variation and that the arterial diameter of men are greater than that of women.

KEY WORDS: Arterial system; Liver; Multidetector computed tomography; Variation.

\section{INTRODUCTION}

The liver is the largest organ and gland in the body, located in the right upper quadrant of the abdominal cavity. The liver receives its blood supply from $70 \%$ hepatic portal system and from $30 \%$ hepatic arterial system. The hepatic arterial system anatomy has a variable structure and variation rate varies between $25 \%$ and $75 \%$ (Standring et al., 2008). These vessels may be accessory, occurring in addition to the normal arterial supply, or replaced representing the primary arterial supply to the lobe. These arteries arise from superior mesenteric artery (SMA), left gastric artery (LGA), abdominal aorta (AA) or other visceral branches (Hiatt $e t$ al., 1994).

Liver transplantation, laparoscopic cholecystectomy and other liver surgeries have caused increased interest in the liver arterial system anatomy (Chen et al., 2009). Arterial variations are important in the planning and performance of all surgical and radiological procedures in the upper abdomen. However, surgical errors resulting from the inability to understand the anatomy of the liver arterial system cause serious consequences and even mortality for patients (Singh et al., 2014). For this reason, many studies examining the anatomy and variations of the liver arterial system have been conducted and the Michels Classification has been defined as the most accepted classification in the literature (Michels, 1951; Gruttadauria et al., 2001; Brandhagen et al., 2003; Koops et al., 2004; Prabhasavat \& Homgade, 2008; PérezSaborido et al., 2012).

Knowing the diameter of hepatic arteries is the great importance for vascular and biliary reconstruction, hepatic artery thrombosis and especially liver transplantation (Douard et al., 2002). In addition, arterial diameters must be known for the correct selection of the catheter in the

\footnotetext{
${ }^{1}$ Afyonkarahisar Health Sciences University, Medicine Faculty, Department of Anatomy, Afyonkarahisar, Turkey.

${ }^{2}$ Selcuk University, Medicine Faculty, Department of Anatomy, Konya, Turkey.

${ }^{3}$ Selcuk University, Medicine Faculty, Department of Radiology, Konya, Turkey.
} 
treatment of angioplasty, angiography and hepatic metastatic tumors (Watanabe et al., 2005). However, information about artery diameters is still insufficient (Da Silveira et al., 2009).

Although sufficient information is available in the literature on the anatomy and variations of the liver arterial system, there is no comprehensive study on the relationship between anatomical variations and artery diameters. Therefore, in this study, it was aimed to examine the anatomy and variations of the hepatic arterial system and measure the diameters of the related arteries with Multidetector Computed Tomography (MDCT) images.

\section{MATERIAL AND METHOD}

The study was carried out on the images obtained from the MDCT device (Sensation 64, Siemens, Erlangen, Germany) serving in the Selçuk University Department of Radiology, after permission of Non-Interventional Clinical Research Ethics Committee was obtained (Selçuk University, 218/312-12.09.2018). A total of 500 patients were included in the study, including 216 women (16-90) and 284 men (1490). 13 patients with circulatory and vascular diseases or who could not been obtained optimal images were excluded from the study because they fell outside the study criteria.

While the patients were in supine position, the measurements were performed on the $0.3 \mathrm{~mm}$ sectional abdominal images (from diaphragm to pubic region) taken in the arterial phase using MDCT. Using the Enlil Pacs imaging program (Enlil PACS Viewer, Eroglu Yazılım, Eskisehir, Turkey) at the workstation, hepatic arterial system (AA, celiac trunk (CT), common hepatic artery (CHA), proper hepatic artery (PHA), right hepatic artery (RHA), left hepatic artery (LHA) variations, localization, initial diameter and relationships with other arteries were recorded. While the diameters of hepatic arterial system vessels were measured on the axial plan, the variations of the related arteries were determined on the coronal plan. The Michels classification was taken as reference in the examination of variation situations (Michels).

Statistical analysis of the data was done with SPSS version 19.0 package program (SPSS Inc., Chicago, IL, USA). Statistical analysis included means, standard deviations and percentages of the data. Kolmogorov-Smirnov test was used to suitability of the data for normal distribution and it was determined that datas were not homogeneous. Mann-Whitney $\mathrm{U}$ test was used for binary group comparisons in which the significant difference between the sexes and the variant/normal measurements were evaluated. The relationship between variation incidence and sex was analyzed by Chi-square test. The results were evaluated in the $95 \%$ confidence interval and the data with $\mathrm{p}$ value less than $\mathrm{p}<0.05$ were considered statistically significant.

\section{RESULTS}

The mean age of the 500 patients in the study was $60.4 \pm 17$, the mean age of 216 women was $61.1 \pm 17.1$, and the mean age of 284 men was $59.9 \pm 16.9$.

In the study, the data were analyzed and evaluated statistically in two main groups; variations of the hepatic arterial system and diameter measurements of these arteries.

Variations of the hepatic arterial system. Classic anatomy (Type I, Fig. 1) was observed in 428 (85.6 \%) of 500 cases, and also hepatic arterial system variation was found in 72 (14.4 $\%$ ) of them. In cases with variation, Type III (Fig. 2) was detected in 63 cases (87.5\%), Type II (Fig. 3) in five cases $(6.9 \%)$ and Type IV (Fig. 4$)$ in one case $(1.4 \%)$. In addition to these, we found three rare variations that not defined in the Michels classification. Two of these were the replaced LHA originated from CHA (Fig. 5), and the other one was the the replaced RHA originated from CT (Fig. 6) was recorded. The distribution of variations by sex was shown in Table I.

The frequency of hepatic arterial variations and the relationship between sexes were analyzed. Depending on this result, no statistically significant relationship was found between the frequency of variation and $\operatorname{sex}(\mathrm{p}=0.068)$.

Diameter measurements of the hepatic arterial system. In this study, the transverse diameter of AA, the initial diameters of CT, CHA, PHA, RHA, LHA were examined according to sex and overall distribution. Arterial diameter measurements; classical anatomy, variational anatomy and all cases were evaluated separately (Table II).

When the diameter measurements of cases compatible with classical anatomy and variational anatomy were examined, it was determined that CHA and PHA diameters were larger in cases compatible with classical anatomy and LHA diameter was larger in cases with variations. And these differences were founded statistically significant $(\mathrm{p}<0.05)$.

When the arterial diameter measurements were compared by sex, it was found that all means were greater in men than in women. Except for the PHA diameter, all these measurement differences were statistically significant $(\mathrm{p}<0.05)$. 


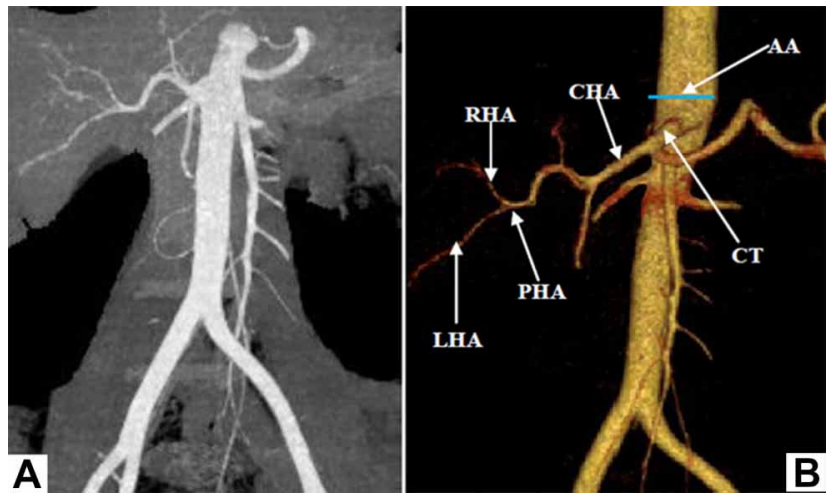

Fig. 1. A. Arterial system compatible with Michels Type I on coronal section, B. Arterial system compatible with Michels Type I on inspace coronal section.
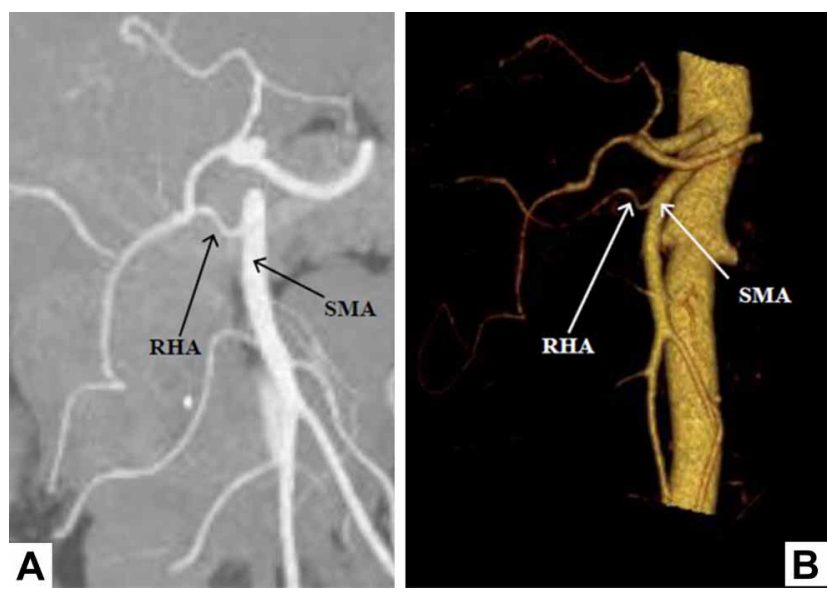

Fig. 2. A. Arterial system compatible with Michels Type III on coronal section, B. Arterial system compatible with Michels Type III on inspace coronal section. SMA; superior mesenteric artery, RHA; right hepatic artery.
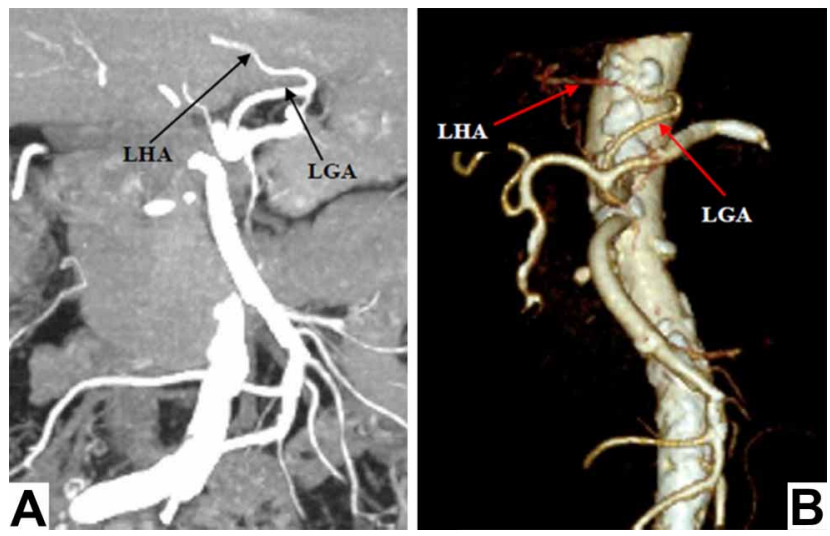

Fig. 3. A. Arterial system compatible with Michels Type II on coronal section, B. Arterial system compatible with Michels Type II on inspace coronal section. LGA; left gastric artery; LHA; left hepatic artery.
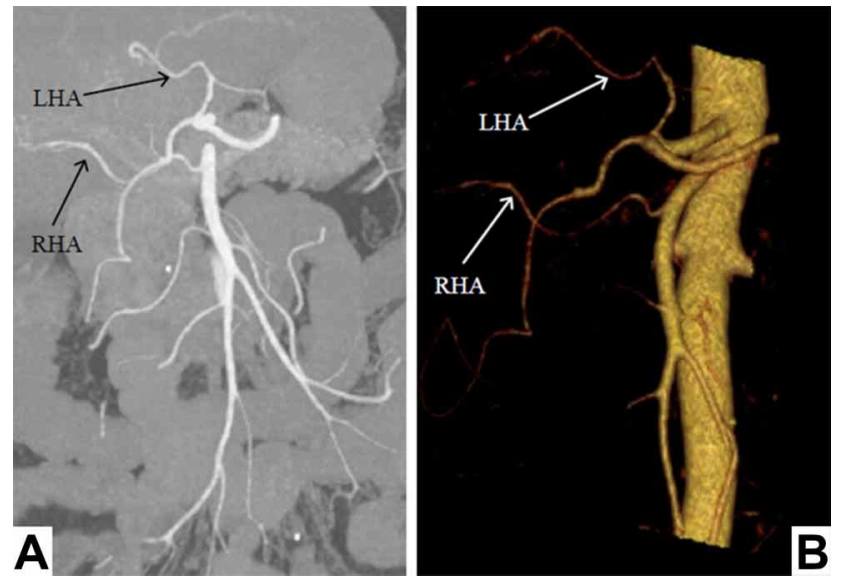

Fig. 4. A. Arterial system compatible with Michels Type IV on coronal section, B. Arterial system compatible with Michels Type IV on inspace coronal section. RHA; right hepatic artery; LHA; left hepatic artery.
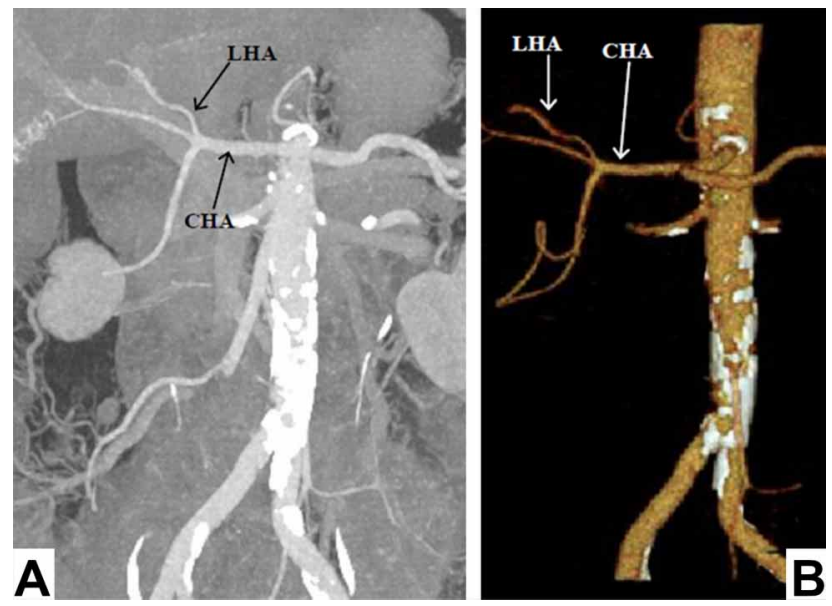

Fig. 5. A. The replaced LHA originated from CHA on coronal section, B. The replaced LHA originated from CHA on inspace coronal section. CHA; a. hepatica communis, LHA; left hepatic artery.
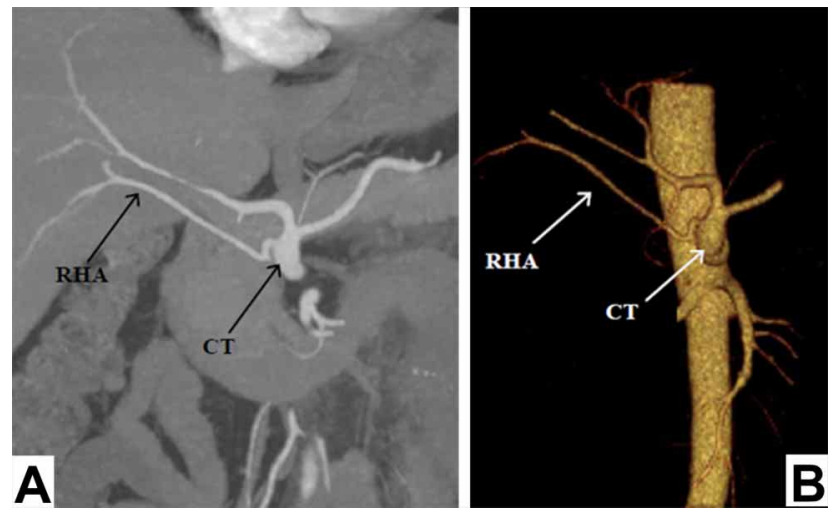

Fig. 6. A. The replaced RHA originated from CT on coronal section, B. The replaced RHA originated from CT on inspace coronal section. CT; celiac trunk, RHA; right hepatic artery. 
Table I. Common and rare types of hepatic arterial system variations and distribution by sex according to Michaels Classification.

\begin{tabular}{|c|c|c|c|c|c|c|c|c|c|c|c|}
\hline & Type I & Type II & Type & Type & Type V & Type & Type & Type & Type & Type X & Rare \\
\hline Male & 236 & 2 & 42 & 1 & - & - & - & - & - & - & 3 \\
\hline Female & 192 & 3 & 21 & - & - & - & - & - & - & - & - \\
\hline Total & 428 & 5 & 63 & 1 & - & - & - & - & - & - & 3 \\
\hline
\end{tabular}

Table II. Diameter measurements of cases compatible with classical anatomy, variational anatomy and all cases by sex.

\begin{tabular}{|c|c|c|c|c|c|}
\hline & Artery & Female & Male & Total & P Value \\
\hline \multirow{6}{*}{ 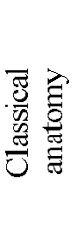 } & Abdominal aorta & $20.54 \pm 2.59$ & $22.91 \pm 3.1$ & $21.85 \pm 3.11$ & $<0.001 *$ \\
\hline & Celiac trunk & $6.57 \pm 0.92$ & $7.32 \pm 1.22$ & $6.99 \pm 1.1$ & $<0.001 *$ \\
\hline & Common hepatic & $4.76 \pm 1.06$ & $5.32 \pm 1$ & $5.07 \pm 1.06$ & $<0.001 *$ \\
\hline & Proper hepatic & $3.68 \pm 0.94$ & $3.95 \pm 0.94$ & $3.83 \pm 0.95$ & $0.014 *$ \\
\hline & Right hepatic & $2.76 \pm 0.76$ & $2.96 \pm 0.83$ & $2.87 \pm 0.8$ & $0.010^{*}$ \\
\hline & Left hepatic & $1.98 \pm 0.71$ & $2.18 \pm 0.68$ & $2.09 \pm 0.7$ & $0.001 *$ \\
\hline \multirow{6}{*}{ 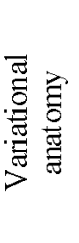 } & Abdominal aorta & $20.35 \pm 1.96$ & $22.75 \pm 2.7$ & $21.95 \pm 2.71$ & $<0.001^{*}$ \\
\hline & Celiac trunk & $6.74 \pm 1.06$ & $7.42 \pm 0.92$ & $7.2 \pm 1.01$ & 0.15 \\
\hline & Common hepatic & $4.3 \pm 0.94$ & $4.74 \pm 0.96$ & $4.59 \pm 0.97$ & 0.60 \\
\hline & Proper hepatic & $2.78 \pm 0.95$ & $3 \pm 0.88$ & $2.93 \pm 0.9$ & 0.37 \\
\hline & Right hepatic & $2.68 \pm 0.55$ & $3.04 \pm 0.97$ & $2.92 \pm 0.87$ & 0.98 \\
\hline & Left hepatic & $2.03 \pm 0.47$ & $2.51 \pm 0.62$ & $2.35 \pm 0.61$ & $<0.001 *$ \\
\hline \multirow{6}{*}{ 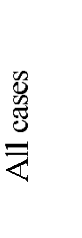 } & Abdominal aorta & $20.52 \pm 2.52$ & $22.88 \pm 3.03$ & $21.86 \pm 0.5$ & $<0.001^{*}$ \\
\hline & Celiac trunk & $6.59 \pm 0.93$ & $7.34 \pm 1.09$ & $7.02 \pm 1.09$ & $<0.001 *$ \\
\hline & Common hepatic & $4.71 \pm 1.06$ & $5.22 \pm 1.01$ & $5 \pm 1.06$ & $<0.001 *$ \\
\hline & Proper hepatic & $3.58 \pm 0.98$ & $3.79 \pm 0.99$ & $3.7 \pm 0.99$ & 0.59 \\
\hline & Right hepatic & $2.75 \pm 0.74$ & $3.04 \pm 0.97$ & $2.88 \pm 0.81$ & $0.02 *$ \\
\hline & Left hepatic & $1.99 \pm 0.68$ & $2.24 \pm 0.68$ & $2.13 \pm 0.69$ & $<0.001^{*}$ \\
\hline
\end{tabular}

Data expressed as $\mathrm{mm} \pm$ standard deviation of mean. * A statistical difference was determined according to sex groups.

\section{DISCUSSION}

In today's conditions, progress in liver surgery and microvascular reconstruction techniques, and improvements in imaging methods both increase surgical success and reduce complications (Orguc et al., 2004). For example, liver and hepatic arterial system surgeries are usually planned according to the classical anatomy pattern. However, arterial system variations are also encountered during surgical dissection. Sometimes, the variations are detected by the leakage that occurs during liver harvesting operation or graft preparation on the "bench". These situations increase arterial complications risk and reveal that variations may be overlooked during surgical dissection (Abdullah et al., 2006). With these examples, importance of the arterial variations detected in the donor and recipient before the operation in reducing the risk of complications was demonstrated (Orguc et al.; Abdullah et al.).

Therefore, images obtained from MDCT angiographies of 500 cases randomly selected from the normal population were used in this study. Hepatic arterial system variations and diameter measurements of the related arteries were evaluated on these images.
There are many studies in the literature on the anatomy and variations of the hepatic arterial system. However, Michels' dissection study performed on 200 cadavers in 1952 is accepted as the basis for the classification of hepatic arterial system anatomy and variations (Michels). In the literature, it was determined that many researchers reference the Michels classification in their studies. The values in these studies are shown in Table III.

As seen in the Table III, it was determined that the most common variation in most studies in the literature was Type III (Hiatt et al.; Gruttadauria et al.; Brandhagen et al.; Koops et al.; Prabhasavat \& Homgade; Kim et al., 2012; PérezSaborido et al.; Taha Ali et al., 2012). In other studies in the literature, the most common variation type was Type II (Todo et al., 1987; Prabhasavat \& Homgade) and Type V (Özbek, 2005). In our study, 500 cases were evaluated according to Michels classification. Classical anatomy (Type I) was found in $85.6 \%$ of the cases and variational anatomy was found in $14.4 \%$. In cases with variation, the most common variation was Type III with a rate of $87.5 \%$ and followed by Type II variation with a rate of $6.9 \%$. In addition, Type IV was found 
Table III. Comparison of hepatic arterial system variations and frequency with literature studies, It was shown according to the Michels classification, values were shown as percentages (\%).

\begin{tabular}{|c|c|c|c|c|c|c|c|c|c|c|c|c|}
\hline Authors & $\begin{array}{c}\text { Case } \\
\text { Count }\end{array}$ & Type I & Type II & $\begin{array}{c}\text { Type } \\
\text { III }\end{array}$ & $\begin{array}{l}\text { Type } \\
\text { IV }\end{array}$ & Type V & $\begin{array}{c}\text { Type } \\
\text { VI }\end{array}$ & $\begin{array}{c}\text { Type } \\
\text { VII }\end{array}$ & $\begin{array}{l}\text { Type } \\
\text { VIII }\end{array}$ & $\begin{array}{c}\text { Type } \\
\text { IX }\end{array}$ & Type X & $\begin{array}{l}\text { Rare } \\
\text { Types }\end{array}$ \\
\hline Michels (1951) & 200 & 55 & 10 & 11 & 1 & 8 & 7 & 1 & 2 & 4,5 & 0,5 & - \\
\hline Hiatt et al., (1994) & 1000 & 75,7 & 9,7 & 10,6 & 2,3 & - & - & - & - & 1,5 & 0,2 & - \\
\hline Gruttadauria et al., (2001) & 701 & 42,2 & - & 14 & - & - & - & - & - & - & - & - \\
\hline Brandhagen et al., (2003) & 89 & 15 & 3,3 & 25 & 1,6 & 3,3 & 18,3 & - & - & - & - & - \\
\hline Koops et al., (2004) & 604 & 79,1 & 2,5 & 8,6 & 1 & 0,5 & 3,3 & 0,2 & 0,2 & 2,8 & - & 1,8 \\
\hline Özbek (2005) & 48 & 54,1 & - & 8,3 & - & 16,6 & - & 4,2 & - & - & - & - \\
\hline Saylisoy et al., (2005) & 52 & 76 & 4 & 10 & 4 & - & - & - & - & 6 & - & - \\
\hline Abdullah et al., (2006) & 932 & 68,1 & 8,1 & 10,2 & 6,4 & 5,8 & - & - & - & - & - & 1,4 \\
\hline Prabhasavat and Homgade (2008) & 200 & 83,5 & 1 & 6 & 0,5 & 3,5 & 0,5 & - & 1 & 0,5 & 2,5 & 2,5 \\
\hline Türk vatan et al., (2008) & 700 & 78,3 & 7,3 & 5,1 & 1,6 & 2 & 2,1 & 0,6 & - & 1,9 & - & 1,1 \\
\hline Silveira et al., (2009) & 21 & 71,4 & 4,8 & 4,8 & - & - & - & - & - & - & - & 19 \\
\hline Todo et al., (2010) & 211 & 64,4 & 12,8 & 9,9 & - & - & - & - & 3,2 & 5 & - & 4,1 \\
\hline Perez et al., (2011) & 325 & 72 & 9,9 & 10,7 & - & - & - & - & - & - & - & 7,4 \\
\hline Taha Ali et al., (2012) & 32 & 59,4 & 6,3 & 15,6 & 3,1 & 9,4 & 3,1 & - & 3,1 & - & - & - \\
\hline Kim et al., (2012) & 104 & 75 & 8,6 & 9,6 & 7,3 & - & - & - & - & - & - & - \\
\hline Present study & 500 & 85,6 & 1 & 12,6 & 0,2 & - & - & - & - & - & - & 0,6 \\
\hline
\end{tabular}

with a rate of $1.4 \%$, while three cases that did not fit the Michels classification were also determined. Among these three cases, two of them were replacement LHA originating from CHA $(2.8 \%)$ and one of them replacement RHA $(1.4 \%)$ originating from CT. Thus, our study was determined as the study with the highest rate of classical anatomy in the literature after Prabhasavat et al. These differences between the literature data are explained by the variability of geographical, ethnic and genetic factors or the embryological development process (as a result of the partial or complete persistence of fetal development) (Özbek).

Knowledge of normal arterial diameters plays an important role in the accurate radiological diagnosis of arterial aneurysms, moreover it reduces complications and increase surgical success (Nghiem et al., 1999). These parameters are great essentials in the determination of anastomosis and reconstruction techniques, choice of the appropriate grafts and stends, vascular modelings, revealing the conditions that may prevent the operation, and the follow-up of liver transplantations (Anton et al., 2018). For example, prior knowledge of normal and expected values for specific arteries can assist in the early diagnosis of an arterial stenosis even before clinical signs of low arterial flow. Another example is the need for anastomosis of the accessory arteries as well as the normal arteries in case of a variation that requires protection from ischemia and additional anastomosis. Therefore, it is also necessary to change the surgical plan (Anton et al.). Otherwise, organ transplantation may result in failure due to graft failure or insufficient regeneration (Winter et al., 1995). For this reason, a detailed evulation of hepatic arterial system morphometry in the preoperative period is essential for a successful transplantation (Vandamme et al., 1969).
There are very few studies in the literature to determine the diameter measurements of the hepatic arterial system. These studies are also limited in terms of their scope, parameters and methodology. The method, sample numbers and measurement values of these studies are shown in Table IV.

Da Silveira et al. cadaver study, Noda et al. (2018) MR and CT angiography and Chen et al. angiography studies were closest to our study in terms of their scope and methodologies.

However, differences were observed in the measurement data of the studies mentioned with our study data. For example, the artery diameters in the study of Da Silveira et al. were larger than our study. This case could be explained by measuring larger vessel diameters due to the nonfunctioning of smooth muscles in cadavers. The artery diameters in the studies of Noda et al. and Chen et al. were smaller than in our study. The reasons for these differences were that Chen et al. measured the inner diameter of arteries with angiography method, and Noda et al. measured the arterial diameters on images of individuals with clinical symptoms using different contrast material and different imaging device. As the general reasons for these discrepancies in measurement values could be explained due to differences in imaging methods and devices, ethnics origin, sex, cadaveric or alive cases, variation types.

Another important point about our results was that the PHA diameter in cases compatible with classical anatomy was greater than $3 \mathrm{~mm}$, and the PHA diameter in cases with variations was less than $3 \mathrm{~mm}$. These values were consistent 
Table IV. Comparison of arterial diameter measurements with literature studies, Data expressed as mm \pm standard deviation of mean, Multidedector Computed Tomography; MDCT, Magnetic Resonance Imaging; MRI, Doppler ultrasonography; DU.

\begin{tabular}{|c|c|c|c|c|c|c|c|c|c|c|}
\hline Authors & Methods & 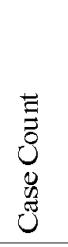 & 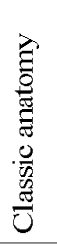 & 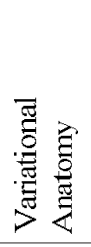 & 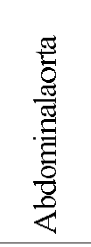 & 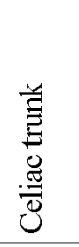 & 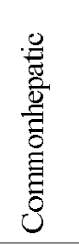 & 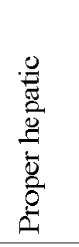 & 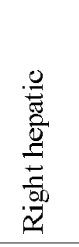 & 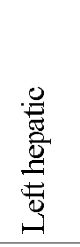 \\
\hline Nghiem et al., (1999) & Transplantation & 80 & $\mathrm{X}$ & & - & - & - & 3 & 3 & 2 \\
\hline Erden et al., (2009) & MRI & 41 & & $\mathrm{X}$ & - & - & 6,7 & - & - & - \\
\hline Silveira et al., (2009) & Cadaver & 21 & $X$ & $\mathrm{X}$ & - & $\begin{array}{l}7,9 \\
7,1\end{array}$ & $\begin{array}{l}5,0 \\
5,2\end{array}$ & $\begin{array}{l}4,5 \\
3,8\end{array}$ & $\begin{array}{c}4 \\
3,2\end{array}$ & $\begin{array}{c}3 \\
2,8\end{array}$ \\
\hline Cherian et al., (2010) & Transplantation & 12 & $X$ & $\mathrm{X}$ & - & - & $\begin{array}{l}4,97 \\
4,99\end{array}$ & - & $\begin{array}{l}4,83 \\
5,19\end{array}$ & - \\
\hline Ergun and Lakadamyali (2010) & DU & 20 & $\mathrm{X}$ & & - & - & - & 4,04 & - & - \\
\hline Y1lmaz et al., (2010) & MDCT & 150 & $\mathrm{X}$ & & 22,6 & 7,2 & - & - & - & - \\
\hline \multirow[t]{2}{*}{ Huang et al.,(2013) } & Angiography & 63 & $X$ & & - & - & - & & 5,6 & - \\
\hline & & & & $X$ & - & - & - & - & 5,5 & - \\
\hline Imakuma et al., (2014) & Cadaver & 16 & $X$ & & - & & - & 4,08 & 3,05 & \\
\hline Singh et al., (2014) & Cadaver & 40 & $\mathrm{X}$ & & - & 6,6 & 5,1 & - & - & - \\
\hline \multirow[t]{2}{*}{ Noda et al., (2018) } & MDCT & 88 & $\mathrm{X}$ & & - & 6,4 & 4,5 & & 3,84 & 3,6 \\
\hline & MRI & & $\mathrm{X}$ & & & 6,13 & 4,4 & & 4,28 & 3,98 \\
\hline Chen et al., (2009) & Angiography & 20 & $\mathrm{X}$ & & - & - & 4,07 & 3,5 & 2,18 & 1,58 \\
\hline Pinal-Garcia et al., (2018) & Autopsy & 140 & $\mathrm{X}$ & & - & 7,2 & - & - & - & - \\
\hline \multirow[t]{2}{*}{ Present study } & MDCT & 500 & $X$ & & 21,85 & 6,99 & 5,07 & 3,83 & 2,87 & 2,09 \\
\hline & & & & $X$ & 21,95 & 7,2 & 4,3 & 2,93 & 2,92 & 2,51 \\
\hline
\end{tabular}

with the studies of Ishigami et al. (2004) and Da Silveira et al. These results draw attention to the knowledge that variational arterial system anatomy increases the risk of complications in the recipient after transplantation and creates a higher risk in hepatic arteries smaller than $3 \mathrm{~mm}$ (Nghiem et al.; Douard et al.; Da Silveira et al.).

In conclusion, hepatic arterial system of 500 cases was evaluated retrospectively on MDCT images in our study. Classical anatomy was found in $85.6 \%$ of the cases and the most common variation was determined as Type III. When arterial diameter measurements were examined, it was found statistically significant that CHA and PHA diameter was larger in cases compatible with classical anatomy, and LHA diameter was larger in cases showing variation. Also, it was determined that the diameter measurements of men were larger than women when these groups were evaluated by sex, and statistically significant difference in all diameters except PHA.

Our study, which examines the frequency of hepatic arterial system variations and the relationship of arterial diameters with sex and variations, is an original study on its scope and sample. We believe that this study will further advance with some modifications and additions and will make a great contribution to the branches of surgery and radiology.
ACKNOWLEDGMENTS. This study has been produced from $\mathrm{PhD}$ thesis.

BILIR, A.; FAZLIOGULLARI, Z.; KOPLAY, M.; UNVER DOGAN, N. \& KARABULUT, A. K. Mediciones de diámetro y variaciones del sistema arterial hepático en imágenes de tomografía computarizada multidetector. Int. J. Morphol., 39(3):869-875, 2021.

RESUMEN: El hígado juega un papel importante en diferentes eventos, tal como la producción de bilis, la filtración de sangre y las funciones metabólicas. El hígado está irrigado por el sistema arterial hepático. La anatomía del sistema arterial hepático tiene una estructura variable y la tasa de variación es alta. En nuestro estudio, nuestro objetivo fue determinar los diámetros y la variación de las arterias que irrigan el hígado con imágenes de tomografía computarizada multidetector. Se evaluaron las variaciones del sistema arterial hepático de 500 casos y se obtuvieron imágenes con tomografía computarizada de detectores múltiples abdominales y se midieron los diámetros de las arterias relacionadas. Se determinaron los diámetros medios de la anatomía clásica y variacional. Según las medidas medias de la anatomía clásica y variacional fueron aorta abdominal $21,95 \mathrm{~mm}$, arteria celíaca $7,2 \mathrm{~mm}$, arteria hepática común 4,3 mm, arteria hepática propia $2,93 \mathrm{~mm}$, arteria hepática derecha $2,92 \mathrm{~mm}$, arteria hepática izquierda arteria $2,51 \mathrm{~mm}$ y parte abdominal de la aorta $21,85 \mathrm{~mm}$, arteria celíaca $6,99 \mathrm{~mm}$, 
arteria hepática común $5,07 \mathrm{~mm}$, arteria hepática propia 3,83 $\mathrm{mm}$, arteria hepática derecha $2,87 \mathrm{~mm}$ y arteria hepática izquierda 2,09 respectivamente. Cuando se evaluó en términos de variaciones, el $85,6 \%$ de los casos tenían ramificaciones según el Tipo I, el 14,4\% de los casos tenían diferentes patrones de ramificación. El tipo III $(87,5 \%)$ fue la variación más observada entre ellos. Como resultado del estudio, se determinó que los diámetros arteriales varían según el estado de variación y que el diámetro arterial de los hombres es mayor que el de las mujeres.

PALABRAS CLAVE: Sistema arterial; Hígado; Tomografía computarizada multidetector; Variación.

\section{REFERENCES}

Abdullah, S. S.; Mabrut, J. Y.; Garbit, V.; De La Roche, E.; Rode, E. O. A.; Morin, A.; Berthezene, Y.; Baulieux, J. \& Ducerf, C. Anatomical variations of the hepatic artery: Study of 932 cases in liver transplantation. Surg. Radiol. Anat., 28(5):468-73, 2006.

Anton, S.; Stahlberg, E.; Horn, M.; Wiedner, M.; Kleemann, M.; Barkhausen, J. \& Goltz, J. P. Initial experience with the E-ventus ${ }^{\circledR}$ stent-graft for endovascular treatment of visceral artery aneurysms. J. Cardiovasc. Surg. (Torino), 59(2):225-31, 2018.

Brandhagen, D.; Fidler, J. \& Rosen, C. Evaluation of the donor liver for living donor liver transplantation. Liver Transpl., 9(10 Suppl. 2):S16-28, 2003.

Chen, H.; Yano, R.; Emura, S. \& Shoumura, S. Anatomic variation of the celiac trunk with special reference to hepatic artery patterns. Ann. Anat., 191(4):399-407, 2009.

Da Silveira, L. A.; Silveira, F. B. C. \& Fazan, V. P. S. Arterial diameter of the celiac trunk and its branches. Anatomical study. Acta Cir. Bras., 24(1):437, 2009.

Douard, R.; Ettore, G. M.; Chevallier, J. M.; Delm \pm S, V.; Cugnenc, P. H. \& Belghiti, J. Celiac trunk compression by arcuate ligament and livingrelated liver transplantation: a two-step strategy for flow-induced enlargement of donor hepatic artery. Surg. Radiol. Anat., 24(5):327-31, 2002.

Gruttadauria, S.; Foglieni, C. S.; Doria, C.; Luca, A.; Lauro, A. \& Marino, I. R. The hepatic artery in liver transplantation and surgery: Vascular anomalies in 701 cases. Clin. Transplant., 15(5):359-63, 2001.

Hiatt, J. R.; Gabbay, J. \& Busuttil, R.W. Surgical anatomy of the hepatic arteries in 1000 cases. Ann. Surg., 220(1):50-2, 1994.

Ishigami, K.; Zhang, Y.; Rayhill, S.; Katz, D. \& Stolpen, A. Does variant hepatic artery anatomy in a liver transplant recipient increase the risk of hepatic artery complications after transplantation? AJR Am. J. Roentgenol., 183(6):1577-84, 2004.

Kim, T. S.; Noh, Y. N.; Lee, S.; Song, S. H.; Shin, M.; Kim, J. M.; Kwon, C. H. D.; Kim, S. J.; Lee, S. K. \& Joh, J. W. Anatomic similarity of the hepatic artery and portal vein according to the donor-recipient relationship. Transplant. Proc., 44(2):463-5, 2012.

Koops, A.; Wojciechowski, B.; Broering, D. C.; Adam, G. \& Krupski-Berdien, $\mathrm{G}$. Anatomic variations of the hepatic arteries in 604 selective celiac and superior mesenteric angiographies. Surg. Radiol. Anat., 26(3):239-44, 2004.

Michels, N. A. The hepatic, cystic and retroduodenal arteries and their relations to the biliary ducts with samples of the entire celiacal blood supply. Ann. Surg., 133(4):503-24, 1951.

Nghiem, H. V.; Dimas, C. T.; McVicar, J. P.; Perkins, J. D.; Luna, J. A.; Winter 3rd, T. C.; Harris, A. \& Freeny, P. C. Impact of double helical CT and three-dimensional CT arteriography on surgical planning for hepatic transplantation. Abdom. Imaging, 24(3):278-84, 1999.
Noda, Y.; Goshima, S.; Namimoto, T.; Shinkawa, N.; Nakagawa, M.; Kajita, K.; Kawada, H.; Kawai, N.; Tanahashi, Y.; Matsuo, M.; et al. Simultaneous acquisition of MR angiography and diagnostic images of abdomen at view-sharing multiarterial phases and comparing the effect of two different contrast agents. J. Magn. Reson. Imaging, 48(1):102-10, 2018.

Orguc, S.; Tercan, M.; Bozoklar, A.; Akyildiz, M.; Gurgan, U.; Celebi, A.; Nart, D.; Karasu, Z.; Icoz, G.; Zeytunlu, M.; et al. Variations of hepatic veins: helical computerized tomography experience in 100 consecutive living liver donors with emphasis on right lobe. Transplant. Proc., 36(9):2727-32, 2004.

Özbek, O. Canlı Karaciger Verici Adaylarında Multidedektör BT Anjiografi Ile Hepatik Arteryel Anatominin Degerlendirilmesi. Thesis. Ankara, Bas,kent University, 2005. Available from: http:// acikerisim.baskent.edu.tr/bitstream/handle/11727/1661/ 00024.pdf?sequence $=3 \&$ isAllowed $=y$

Pérez-Saborido, B.; Pacheco-Sánchez, D.; Barrera Rebollo, A.; Pinto Fuentes, P.; Asensio Díaz, E.; Labarga Rodriguez, F.; Sarmentero Prieto, J. C.; Martínez Díez, R.; Rodríguez Vielba, P.; Martín, M. G.; et al. Incidence of hepatic artery variations in liver transplantation: does it really influence short- and long-term results? Transplant. Proc., 44(9):2606-8, 2012.

Prabhasavat, K. \& Homgade, C. Variation of hepatic artery by 3-D reconstruction MDCT scan of liver in Siriraj Hospital. J. Med. Assoc. Thai., 91(11):1748-53, 2008.

Singh, B. G. P.; Bhatt, C. R.; Patel, S. V. \& Mehta, C. D. Morphometric Study of coeliac trunk specific reference to hepatic artery pattern in the West-Indian population. Indian J. Surg., 76(5):359-62, 2014.

Standring, S. Gray's Anatomy. The Anatomical Basis of Clinical Practice. 40th ed. London, Elsevier Health Sciences, 2008.

Taha Ali, T. F.; Tawab, M. A.; EL-Hariri, M. A. \& EL-Shiekh, A. F. Preoperative hepatic vascular mapping of living donor for liver transplantation using 64-MDCT. Egypt. J. Radiol. Nucl. Med., 43(3):32536, 2012.

Todo, S.; Makowka, L.; Tzakis, A. G.; Marsh Jr., J. W.; Karrer, F. M.; Armany, M.; Miller, C.; Tallent, M. B.; Esquivel, C. O. \& Gordon, R. D. Hepatic artery in liver transplantation. Transplant. Proc., 19(1 Pt. 3):2406-11, 1987.

Vandamme, J. P.; Bonte, J. \& Van der Scheueren, G. A revaluation of hepatic and cystic arteries. The importance of the aberrant hepatic branches. Acta Anat. (Basel), 73(2):192-209, 1969.

Watanabe, M.; Takita, W.; Tsuchiya, M.; Otsuka, Y.; Tamura, A.; Kaneko, H. \& Kobayashi, K. Hepatic arterial cannulation using the side holed catheter. J. Surg. Oncol., 91(2):145-9, 2005.

Winter 3rd, T. C.; Freeny, P. C.; Nghiem, H. V.; Hommeyer, S. C.; Barr, D.; Croghan, A. M.; Coldwell, D. M.; Althaus, S. J. \& Mack, L. A. Hepatic arterial anatomy in transplantation candidates: evaluation with three-dimensional CT arteriography. Radiology, 195(2):363-70, 1995.

\author{
Corresponding author: \\ Abdulkadir Bilir \\ Afyonkarahisar Health Sciences University \\ Medicine Faculty \\ Department of Anatomy \\ Afyonkarahisar \\ TURKEY
}

Orcid no: 0000-0003-0633-9542

E-mail: fztabdulkadirbilir@gmail.com

Received: 25-02-2021

Accepted: 05-04-2021 